\title{
Guest editorial: ICT in Education
}

\author{
Reuben Dlaminia Reuben.Dlamini@wits.ac.za, \\ Emma Coleman Emma.Coleman@wits.ac.za \\ a Wits School of Education, University of the Witwatersrand \\ b School of Economic \& Business Sciences, University of the Witwatersrand
}

This special edition is being published at a time when there is lack of formal research and under theorization of ICT integration into teaching and learning in South Africa. With many initiatives still dominated by the procuring of computational infrastructure equating it to pedagogical ICT integration in schools. Most ICT initiatives are not informed by research thus lack theoretical grounding and systematic approach, yet ICT needs to be conceptualized in its many facets and its manifold impacts on societies. Too often the initiatives follow personal interests regulated by service providers and that does not guarantee success as its sequence design and implementation activities are not conceptualized around education needs. The limited use of technology by teachers brings with it social, economic, and cultural contextual constraints and concerns about social and cultural capital in the integration of ICT in schools (Belland, 2009; Dasuki, 2012). The misconception is that provisioning of computing devices and basic ICT training prepares teachers for quality ICT pedagogical integration.

The White Paper on e-Education (Department of Education, RSA, 2004) states that ICT offers greater opportunities to access learning, redress inequalities and improve the quality of teaching and learning. As the White paper on e-Education puts it, there is compelling international and local research evidence that, under the right conditions, "investments in ICTs yield positive results for learners and teachers ... [including] knowledge for the real world; the ability of learners to manage learning; ... and accessing information that increases knowledge, inquiry and depth of investigation" [cl. 2.19](Department of Education, RSA, 2004). In many cases teachers end up using computers to re-present information instead of using it to "improve the capability to generate thought." (Hokanson \& Hooper, 2000). It is clear that the discourse on 'ICT in Education' has not been adequately debated and researched scientifically in the South African context. In fact there is lack of empirical work to ground the discourse. Howard and Maton (2011) assert that intellectual fields that lack explicit, powerful theoretical frameworks capable of underpinning empirical research tend towards repetition, fragmentation and segmentation.

Provincial governments are making significant investments every year on computing devices, yet there is no correlation between the money spent and the uptake of computers for teaching and learning in schools. Evidently, it is important to have a deeper understanding of ICT innovations and how they shape new digital pedagogies and practices to release the potential of digital technologies

Dlamini, R. and Coleman, E. (2017). Guest editorial: ICT in Education [Guest Editorial]. South African Computer Journal 29(2), vii-x. https://doi.org/10.18489/sacj.v29i2.547

Copyright (C) the author(s); published under a Creative Commons NonCommercial 4.0 License (CC BY-NC 4.0).

$S A C J$ is a publication of the South African Institute of Computer Scientists and Information Technologists. ISSN 1015-7999 (print) ISSN 2313-7835 (online). 
in cognitive development. The proliferation of such ubiquitous technologies demands improved quality of teaching and learning in the schooling system in order to improve learner attainment. Although the initiatives undertaken by provincial governments have had mixed success, one area that has improved is the number of computers available in schools. However in order to benefit from the ICT's incredible potential to improve teaching and learning, we must work through the 'pedagogical discourse' lens taking into account the social and cultural capital of educators in the integration of ICT in schools.

Yes, ICT presents tremendous opportunities and innovations to improve learners' attainment and enhance their educational experience, but paying scant attention to computing infrastructure limits the discourse of ICT in schools. This special issue is positioned to bring together distributed research to inform teaching and learning using various technological innovations and digital pedagogies. Although researchers have been presenting on the topic at different conferences, journals associated with the conferences do not publish papers on 'ICT in Education'. These researchers end up targeting international journals, yet their work speaks to the South African context. Though ICT has the potential to transform and inspire new digital pedagogies our education system has remained unresponsive due to lack of systematic approach to ICT adoption, appropriation and integration.

Despite all the benefits from the ICT's incredible potential to improve teaching and learning, in South Africa the affordances have not been fully realized. Omolola Ola Bankole and Isabella Venter report on the "Insights into the Use and Affordances of Social and Collaborative Applications for Student Projects." The authors conducted an exploratory research to provide insights into the use of social and collaborative applications by Computer Science students, and the emergent affordances student project teams have created with the use of these applications. Their findings show that the university's elearning platform is utilized for some of their courses; however students seem to prefer free and open source platforms. Student project teams used applications such as WhatsApp, Telegram, Dropbox, Google Drive, Google Docs as well as email messages to work jointly. The authors concluded that students' affordances of social media and collaborative applications are communicative-affordance, document share-affordance, course resource-affordance, and integrityaffordance.

Elmarie Kritzinger reports on "Growing a cyber-safety culture amongst school learners in South Africa through gaming." The aim of the research was to establish if a game based approach can be used to improve cyber safety awareness. This research proposes a short-term initiative in the form of a game-based approach, which will assist school learners in becoming more cyber safe and teach learners about the relevant cyber-related risks and threats. Keshnee Padayachee reports on "A Snapshot Survey of ICT Integration in South African Schools." The aim of this research was to determine the extent of ICT usage in South African schools in order to obtain an understanding of the practical enforcement of ICTs at the school level. The results found that the uptake of technology remains low, on average the frequency of usage per tool type was as follows: contextual tools (41\%), sharing information and ideas tools (29\%), experiential tools (26\%) and reflective dialogue tools $(18 \%)$. It was found that teachers are uncertain with respect to the enforcement of e-education while being encumbered by poor infrastructure and lack of computing skills.

In "A conceptual framework to understand teachers' Professional Dispositions and Orientation 
towards Tablet Technology in secondary schools" Suzanne Sackstein and Lynne Slonimsky report on a conceptual framework developed to provide a more principled and evidenced-based understanding of the issues underlying teachers' technology adoption decisions constructed from Hoadley and Ensor (2009)'s conception of teachers' Professional Dispositions derived from the work of Bernstein on the pedagogic discourse alongside Hooper and Rieber (1995)'s model on educational technology adoption. This framework help shed light on teachers' differential adoption of tablet technology in contexts and settings where tablet technology is either available; being advocated by school management; or even required by the educational stakeholders and government policies.

Brenda Scholtz, Mando Kapeso, and Ruth de Villiers investigated "The Usefulness and Ease of Use of a Mobile Simulation Application for Learning of Enterprise Resource Planning (ERP) Systems." This study investigates and evaluates the Perceived Ease of Use (PEOU) and Perceived Usefulness (PU) of the proposed SYSPRO Latte application. The SYSPRO Latte application an m-learning simulation application was designed based on experiential learning theory. The results revealed that students perceived SYSPRO Latte to be easy to use and useful, and verified other studies identifying a correlation between PEOU and PU. The study also confirmed the benefits of simulation-based learning and m-learning particularly for content presentation.

This special edition focuses on research that helps us to understand how ICT tools can be used to transform classroom experience and enhance teaching and learning. We are of the view that ICT tools open up exciting and innovative instructional techniques that may be used to overcome student passiveness and enhance critical thinking skills (Tan, 2012; Laxman, 2010; Chiu, 2009, 1; Yang \& Chou, 2008). We therefore invited the submission of papers for this special issue to gather a collection of high-quality papers that reflect various perspectives on 'ICT in Education'.

\section{References}

Belland, B. (2009). Using the theory of habitus to move beyond the study of barriers to technology integration. Computers and Education, 52(2), 353-364. https://doi.org/10.1016/j.compedu. 2008.09.004

Chiu, Y. (2009). Facilitation Asian students' critical thinking in online discussions. British Journal of Educational Technology, 40, 42-57. https://doi.org/10.1111/j.1467-8535.2008.00898.x

Dasuki, I. (2012). Investigating the link between ICT intervention and human development using the capability approach: A case study of the computerised electricity management system (Doctoral dissertation, Brunel University).

Department of Education, RSA. (2004). White paper on e-education.

Hoadley, U. \& Ensor, P. (2009). Teachers' social class, professional dispositions and pedagogic practice. Teaching and teacher education, 25(6), 876-886. https://doi.org/10.1016/j.tate.2009.01. 014

Hokanson, B. \& Hooper, S. (2000). Computers as cognitive media: Examining the potential of computers in education. Computers in Human Behavior, 16, 537-552. https://doi.org/10. 1016/S0747-5632(00)00016-9 
Hooper, S. \& Rieber, L. (1995). Teaching with technology. In A. Ornstein (Ed.), Teaching: theory into practice. Allyn and Bacon.

Howard, S. \& Maton, K. (2011). Theorising knowledge practices: a missing piece of the educational technology puzzle. Research in Learning Technology, 19(3), 191-206. https://doi.org/10. 3402/rlt.v19i3.17109

Laxman, K. (2010). A conceptual framework mapping the application of information search strategies to sell and ill-structured problem solving. Computers and Education, 55(2), 513-526. https: //doi.org/10.1016/j.compedu.2010.02.014

Tan, S. (2012). Enhancing critical thinking skills through online tools: A case of teacher trainees. OIDA International Journal of Sustainable Development, 3(7), 87-98.

Yang, Y.-T. \& Chou, H.-A. (2008). Beyond critical thinking skills: Investigating the relationship between critical thinking skills and dispositions through different online instructional strategies. British Journal of Educational Technology, 39(4), 666-684. https://doi.org/10.1111/j.14678535.2007.00767.x 